International Journal of Civil Engineering and Technology (IJCIET)

Volume 9, Issue 9, September 2018, pp. 1036-1046, Article ID: IJCIET_09_09_100

Available online at http://www.iaeme.com/ijciet/issues.asp?JType=IJCIET $\&$ VType=9\&IType=9

ISSN Print: 0976-6308 and ISSN Online: 0976-6316

\title{
STRATEGY FOR IMPROVING SCIENCE AND WELFARE THROUGH COMMUNITY EMPOWERMENT TECHNOLOGY
}

\author{
A. I. F. Lubis, A. P. U. Siahaan, Diwayana Putri Nasution, Ade Novalina, Rusiadi, \\ Rahmad Sembiring, Bakhtiar Efendi and Febru Winaro \\ Universitas Pembangunan Panca Budi, Medan, Indonesia
}

\begin{abstract}
The strategy being developed by the government is the Process Hierarchy Analysis (AHP) which includes government policies, service quality, development of capital access, and construction of school facilities, construction of facilities and infrastructure, access to fisheries resources, skills development, and technological mastery. With the development strategy of coastal development is expected to be a solution where the solution needs to be done through a comprehensive strategy by placing socio-economic systems and cultural values that have been embedded in the community as a driving factor for change. CFA Test: From the KMO and Bartlett's Test table, the Kaiser Mayer Olkin (KMO) value is 0.547 where the value is greater than 0.5. This value indicates that the data is valid for further analysis by factor analysis. Bartlett test value is 53.965 with a significant value of 0.002 far below 5\%, so the correlation matrix formed is an identity matrix, or in other words, the model of the factor used is excellent. The method in this study is to use CFA (Confirmatory Analysis Factors) to choose which variables affect the dependent variable and multiple regression analysis methods that aim to analyze the effect of independent variables on the dependent variable separately or together.
\end{abstract}

Keywords: Welfare, economic empowerment, CFA, AHP

Cite this Article: A. I. F. Lubis, A. P. U. Siahaan, Diwayana Putri Nasution, Ade Novalina, Rusiadi, Rahmad Sembiring, Bakhtiar Efendi and Febru Winaro, Strategy for Improving Science and Welfare through Community Empowerment Technology, International Journal of Civil Engineering and Technology, 9(9), 2018, pp. 10361046.

http://www.iaeme.com/IJCIET/issues.asp?JType=IJCIET \&VType=9\&IType=9 


\section{INTRODUCTION}

The government has an essential role in every program made to improve the welfare of coastal communities. The government's strategy in tackling the welfare of coastal communities has been a little overcome in efforts to increase coastal development. The strategy being developed by the government is the Analytical Hierarchy Process (AHP) [1][3] which includes government policies, service quality, development of capital access, construction of school facilities, construction of facilities and infrastructure, access to fisheries resources, skills development, and technological mastery [4]-[6]. With the development strategy of coastal development is expected to be a solution where the solution needs to be done through a comprehensive strategy by placing socio-economic systems and cultural values that have been embedded in the community as a driving factor for change.

Table 1 Number of Families According to Welfare Level

\begin{tabular}{|c|c|c|c|c|c|}
\hline & Pra-S & KS-I & KS-II & KS-III & KS-III Plus \\
\hline Sei Balai & 315 & 1558 & 3111 & 1348 & 1497 \\
\hline Tanjung Tiram & 3566 & 4221 & 9145 & 413 & - \\
\hline Talawi & 373 & 3136 & 3696 & 4962 & 2993 \\
\hline Lima Puluh & 2913 & 3357 & 7491 & 6714 & 2549 \\
\hline Air Putih & 1536 & 2545 & 4306 & 3989 & 368 \\
\hline Sei Suka & 251 & 402 & 609 & 8989 & 3311 \\
\hline Medang Deras & 1363 & 2092 & 4877 & 3801 & 900 \\
\hline Batu Bara & 10317 & 17311 & 33235 & 30216 & 11618 \\
\hline
\end{tabular}

From the data above, it is known that the highest number of pre-prosperous families is in Tanjung Tiram Subdistrict, where Tanjung Tiram District is the closest to the sea compared to other areas in the Coal Regency. Pahlawan Village in Tanjung Tiram Subdistrict is the village closest to the sea or commonly called the coastal area. The low level of welfare of Pahlawan Village community is partly due to the lack of coastal development where government policies that have not touched the coastal areas of Pahlawan Village such as in matters of public services, capital, facilities and infrastructure and so on.

The reality of the life of the fishing community with the abundant potential of Indonesian fishery resources, especially small-scale individual traditional fishermen, where the problem is originated from the lack of capital to go to sea, such as ships, fishing gear, and other fishing needs [7]. Those who tend to be unable to avoid being fishermen are forced to borrow money or capital to get all the necessities to go to sea. But the phenomenon found that for almost two years most of the coastal fishermen in the village of Pahlawan no longer have activities that can generate income because of reduced sea yield. From the results of preliminary interviews and observations of the author, that the welfare of fishermen in the Pahlawan Village affects a lot of their income in terms of fishing, which depends on the current weather forecast. Full of uncertainty about the results of catching so that it affects income. Not to mention if the weather is terrible, the fishermen cannot go to sea for days. In addition, the level of nutritional adequacy of fishermen is also considered very low, because fishermen rarely eat their own catch. All fishermen's catches are sold and processed for their own families. The results of this study are expected to be an input for the government in assessing the success of the coastal community welfare improvement strategy that is being carried out, for the fishermen are expected to be able to open their minds and add insight to become more qualified human beings and able to explore the potential of human resources and natural resources the village and make it an economic value that must be supported by the government. 
A. I. F. Lubis, A. P. U. Siahaan, Diwayana Putri Nasution, Ade Novalina, Rusiadi, Rahmad Sembiring, Bakhtiar Efendi and Febru Winaro

\section{THEORIES}

\subsection{Coastal Development}

Coastal communities can be illustrated as groups of people who live in coastal areas and have a source of economic life that depends directly on the use of marine and coastal resources [8]-[10] They consist of fishermen owners, fishermen workers, fish cultivators, and other marine organisms, fish traders, fish processors, as well as suppliers of fisheries production facilities. The coastal area is a place for fish landings and various marine resources and other resources to flow to the mainland. In the direction of the land flowing resources to be channeled to the ocean (and also air) through coastal areas [11]. Historically, the coastal area has become a concentration of various port cities and centers of global growth. When viewed from the regional economy, various coastal regions that have strategic positions in the allocation structure and distribution of economic resources are called to have high locational rent [12].

\subsection{Welfare Strategy}

The measurement of family or household welfare becomes more complicated because the family consists of individuals who live together and interact to achieve the same goals of family welfare [13]-[15] Various indicators or measurements of family welfare have been used, but there are no appropriate or ideal measures to measure family welfare [16]. The content of the analysis generally shows that family welfare is described regarding health aspects, economic factors, healthy family life, education, community life, and community support and diversity and culture [17]-[19].

\subsection{Community Economic Empowerment}

Community economic empowerment is a strengthening of ownership of production factors, strengthening control of distribution and marketing, strengthening communities to get adequate salaries/wages, and strengthening communities to obtain information, knowledge, and skills, which must be done in a multi-aspect, both from the aspect of the community itself or the policy aspect [20][21]. Community economic empowerment efforts are inseparable from expanding employment opportunities and increasing community income.

The theory of community economic empowerment is critical to place humans at the primary level, given the economic power of the community is more dominant moving to the informal sector [22]. To be able to run as a social process, economic empowerment must be able to place the community as its primary benchmark. This role placement is defined as an economic empowerment mechanism that will be carried out according to the potential they have. However, the mechanism for determining empowerment policies that can accommodate the aspirations of all people is not simple. The level of education and resources that are owned will affect the form of the economic sector that will be an option in order to improve a more decent standard of living [23].

\section{METHODOLOGY}

Quantitative analysis in this study is to predict and control a symptom in the strategy to improve the welfare of fishers through economic empowerment of coastal communities in Pahlawan Village, Tanjung Tiram District, Batu Bara Regency. 


\subsection{Confirmatory Factor Analysis (CFA)}

Confirmatory Factor Analysis aims to find a way to summarize the information in the original (initial) variable into a set of new dimensions or factors with the formula:

$$
\mathrm{Xi}=\mathrm{Bi} 1 \mathrm{~F} 1+\mathrm{Bi} 2 \mathrm{~F} 2+\mathrm{Bi} 3 \mathrm{~F} 3+\ldots \ldots \ldots \ldots \ldots+\mathrm{Vi} \mu \mathrm{i}
$$

Where:

$\mathrm{Xi}=$ standardized $\mathrm{i}$ variable

$\mathrm{Bij}=$ partial regression coefficients for variables $\mathrm{i}$ in the $\mathrm{jth}$ common factor

$\mathrm{Fj}=$ common factor $\mathrm{i}$

$\mathrm{Vi}=$ Regression coefficients are standardized for the $\mathrm{i}$ variable on the unique factor $\mathrm{i}$

$\mu \mathrm{i}=$ Unique factor $\mathrm{i}$ variable

Multiple regression analysis is used to determine the direction and magnitude of the influence of the independent variable on the dependent variable (Suharyadi, 2008). In this study conducted to determine whether there is an influence between women's activities of coastal fishers in improving family welfare. Mathematically the equation can be formulated as follows:

$$
Y=a+b 1 \times 1+b 2 \times 2+b 3 \times 3+b 4 x 4+b 5 \times 5+b 6 \times 6+b 7 \times 7+b 8 \times 8+e
$$

Where:

$\mathrm{Y}=$ Community Economic Empowerment

$\mathrm{A}=$ constant

$\mathrm{x} 1, \mathrm{x} 2, \mathrm{x} 3, \mathrm{x} 4, \mathrm{x} 5, \mathrm{x} 6, \mathrm{x} 7, \mathrm{x} 8$

$=$ Dominant Variable / Dominant Factor

$\mathrm{e}=$ Error term.

$\mathrm{b}=$ Regression Coefficient

\section{RESULT AND DISCUSSION}

\subsection{CFA Data Analysis Results}

The researchers conducted and applied descriptive analysis techniques, namely by analyzing and grouping to analyze the research data. Then interpreted so that a real picture of the problem under study will be obtained. Furthermore, factor analysis is conducted which aims to find a way to summarize the information in the original variable (initial) into a set of new dimensions or variables (factors). Data processing uses the SPSS program, with the following results:

Table $2 \mathrm{KMO}$ and Bartlett's Test

\begin{tabular}{|c|c|c|}
\hline \multicolumn{2}{|c|}{ Kaiser-Meyer-Olkin Measure of Sampling Adequacy. } & .547 \\
\hline \multirow{3}{*}{ Bartlett's Test of Sphericity } & Approx. Chi-Square & 53.965 \\
\cline { 2 - 3 } & Df & 28 \\
\cline { 2 - 3 } & Sig. & .002 \\
\hline
\end{tabular}

Furthermore, to see which variables have communalities correlation values above or below 0.5 or above $50 \%$ can be seen in the following table. 
A. I. F. Lubis, A. P. U. Siahaan, Diwayana Putri Nasution, Ade Novalina, Rusiadi, Rahmad Sembiring, Bakhtiar Efendi and Febru Winaro

Table 3 Communalities

\begin{tabular}{|c|c|c|}
\hline & Initial & Extraction \\
\hline Government policy & 1.000 & .444 \\
\hline Service quality & 1.000 & .723 \\
\hline Development of Capital Access & 1.000 & .537 \\
\hline School Facilities Development & 1.000 & .578 \\
\hline $\begin{array}{c}\text { Construction of Facilities and } \\
\text { Infrastructure }\end{array}$ & 1.000 & .561 \\
\hline Access Fish Resources & 1.000 & .494 \\
\hline Skills Development & 1.000 & .722 \\
\hline Use of technology & 1.000 & .550 \\
\hline \multicolumn{2}{|c|}{ Extraction Method: Principal Component Analysis. } \\
\hline
\end{tabular}

Table 4 Total Variance Explained

\begin{tabular}{|c|c|c|c|c|c|c|c|c|c|}
\hline & \multicolumn{3}{|c|}{ Initial Eigenvalues } & \multicolumn{3}{|c|}{$\begin{array}{l}\text { Extraction Sums of Squared } \\
\text { Loadings }\end{array}$} & \multicolumn{3}{|c|}{$\begin{array}{c}\text { Rotation Sums of Squared } \\
\text { Loadings }\end{array}$} \\
\hline & Total & $\begin{array}{c}\% \text { of } \\
\text { Variance }\end{array}$ & $\begin{array}{c}\text { Cumulati } \\
\text { ve } \%\end{array}$ & Total & $\begin{array}{c}\% \text { of } \\
\text { Variance }\end{array}$ & $\begin{array}{c}\text { Cumulati } \\
\text { ve } \%\end{array}$ & Total & $\begin{array}{c}\% \text { of } \\
\text { Variance }\end{array}$ & $\begin{array}{c}\text { Cumulati } \\
\text { ve \% }\end{array}$ \\
\hline 1 & 1.881 & 23.513 & 23.513 & 1.881 & 23.513 & 23.513 & 1.597 & 19.966 & 19.966 \\
\hline 2 & 1.520 & 18.998 & 42.511 & 1.520 & 18.998 & 42.511 & 1.582 & 19.775 & 39.741 \\
\hline 3 & 1.208 & 15.104 & 57.615 & 1.208 & 15.104 & 57.615 & 1.430 & 17.874 & 57.615 \\
\hline 4 & .976 & 12.202 & 69.817 & & & & & & \\
\hline 5 & .766 & 9.579 & 79.396 & & & & & & \\
\hline 6 & .653 & 8.164 & 87.560 & & & & & & \\
\hline 7 & .533 & 6.657 & 94.217 & & & & & & \\
\hline 8 & .463 & 5.783 & 100.000 & & & & & & \\
\hline
\end{tabular}

Based on the results of the total variance explained in the initial Eigenvalues table, it is known that there are only three components of the variables that influence the economic empowerment of the community. Eigenvalues show the relative importance of each factor in calculating the variance for the eight variables analyzed. From the table above shows that there are only three factors formed. Because the three factors have a total value of eigenvalues above 1 , that is, 1.881 for factor $1,1.520$ for factor 2 , and 1.208 for factor 3 , so the factoring process stops at three factors that will participate in the next analysis.

Scree Plot

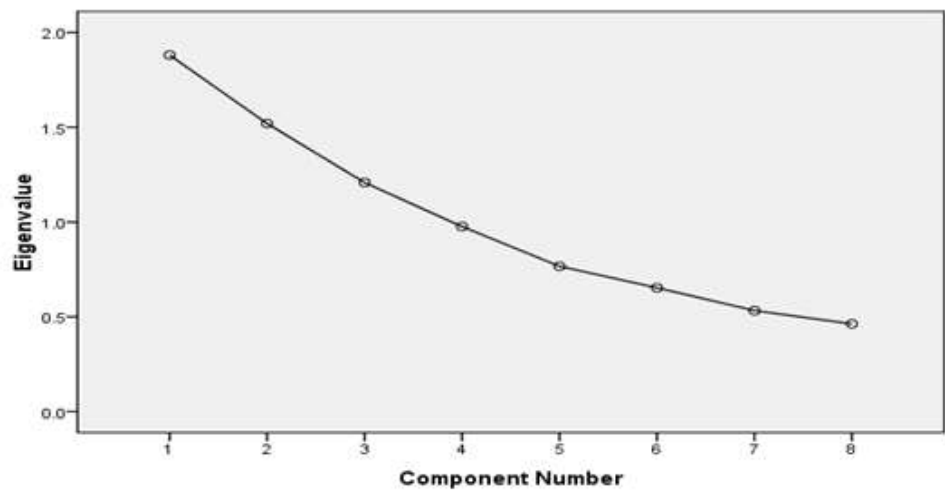

Figure 1 Scree plot Component Number

http://www.iaeme.com/IJCIET/index.asp 1040 editor@iaeme.com


The screen plot graph shows that from one to two factors (the line from the Component Number $=1$ to 2 ), the direction of the graph decreases. Then from number 2 to 3 , the line still decreases. While from number 3 to number 4 is already below the number 1 of the Y-axis (Eigenvalues). It shows that three factors are best for summarizing the eight variables.

Table 5 Component Matrix ${ }^{\mathrm{a}}$

\begin{tabular}{|c|c|c|c|}
\hline & \multicolumn{3}{|c|}{ Component } \\
\hline & 1 & 2 & 3 \\
\hline Government policy & .350 & .304 & .478 \\
\hline Service quality & -.522 & .488 & -.461 \\
\hline Development of Capital Access & .574 & .448 & .080 \\
\hline School Facilities Development & .669 & -.187 & -.308 \\
\hline Construction of Facilities and Infrastructure & -.593 & -.057 & .454 \\
\hline Fish Resource Access & -.387 & .411 & .419 \\
\hline Skills Development & .348 & .770 & .088 \\
\hline Use of technology & -.291 & .435 & -.526 \\
\hline Extraction Method: Principal Component Analysis. \\
\hline a. 3 components extracted. \\
\hline
\end{tabular}

Having known that the three factors are the most optimal number, it can be seen in the Component Matrix table showing the distribution of the eight variables in the three factors formed. While the numbers in the table are factor loadings, which shows the magnitude of the correlation between variables with factor 1 , factor 2 , and factor 3 . The process of determining which variables will go into which factors, is done by doing a large ratio of correlation on each line. In the component, the matrix table shows a correlation above 0.5 . in factor 1 is the development of access to capital and the construction of school facilities. In factor 2, the skill development variable. While in factor 3 there is no correlation above 0.5. Furthermore, the process of Rotation or rotation factor is applied to the factors formed. The purpose of rotation is to clarify variables that fall into certain factors.

Table 6 Rotated Component Matrix ${ }^{\mathrm{a}}$

\begin{tabular}{|c|c|c|c|}
\hline & \multicolumn{3}{|c|}{ Component } \\
\hline & 1 & 2 & 3 \\
\hline Government policy & .575 & .129 & -.311 \\
\hline Service quality & -.044 & .207 & .823 \\
\hline Development of Capital Access & .687 & -.252 & -.044 \\
\hline School Facilities Development & .123 & -.730 & -.173 \\
\hline Construction of Facilities and Infrastructure & -.227 & .707 & -.101 \\
\hline Fish Resource Access & .239 & .653 & .103 \\
\hline Skills Development & .818 & -.002 & .230 \\
\hline Use of technology & .020 & -.016 & .741 \\
\hline Extraction Method: Principal Component Analysis. \\
\hline Rotation Method: Varimax with Kaiser Normalization. \\
\hline Rotation converged in 5 iterations. \\
\hline
\end{tabular}

The result of the rotation process Component Matrix (Rotated Component Matrix) shows a more transparent and more light variable distribution. It was seen that the loading factor that was once small was getting smaller and a large loading factor was increasingly enlarged. 
A. I. F. Lubis, A. P. U. Siahaan, Diwayana Putri Nasution, Ade Novalina, Rusiadi, Rahmad Sembiring, Bakhtiar Efendi and Febru Winaro

Based on the results of the component matrix, it is known that out of eight factors, what is feasible to influence family income are three factors derived from:

- The most significant component 1: Skills Development

- The most significant component 2: Construction of Facilities and Infrastructure

- The most significant component 3: Service Quality

\subsection{Multiple Linear Regression Data Analysis Results}

Table 7 Coefficients

\begin{tabular}{|c|c|c|c|c|c|c|}
\hline \multirow{2}{*}{ Model } & \multicolumn{2}{|c|}{$\begin{array}{c}\text { Unstandardized } \\
\text { Coefficients }\end{array}$} & $\begin{array}{c}\text { Standardized } \\
\text { Coefficients }\end{array}$ & \multirow{2}{*}{ T } & \multirow{2}{*}{ Sig. } \\
\cline { 2 - 5 } \multicolumn{2}{c|}{} & B & $\begin{array}{c}\text { Std. } \\
\text { Error }\end{array}$ & Beta & & \\
\hline \multirow{2}{*}{ (Constant) } & -1062.602 & 741.121 & & -1.434 & .157 \\
\cline { 2 - 6 } & Skills Development & 1165.530 & 229.118 & .513 & 5.087 & .000 \\
\cline { 2 - 5 } & $\begin{array}{c}\text { Construction of Facilities and } \\
\text { Infrastructure }\end{array}$ & 769.398 & 262.285 & .293 & 2.933 & .005 \\
\cline { 2 - 5 } & Service quality & -65.162 & 283.455 & -.023 & -.230 & .819 \\
\hline \multicolumn{2}{|c|}{ Dependent Variable: Community Economic Empowerment } & & \\
\hline
\end{tabular}

$$
\mathrm{Y}=-1062.602+1165.530+769.398-65.162+\mathrm{e}
$$

Interpretation of multiple linear regression equations:

- If skills developments, construction of facilities and infrastructure, and quality of service in the Pahlawan Village are not improved, the economic empowerment of the community will decrease.

- If the community in Pahlawan Village has more than one skill development, community economic empowerment will increase significantly.

- If the development of facilities and infrastructure in Pahlawan Village is getting better, the economic empowerment of the community will increase significantly.

- If the quality of service in Pahlawan Village is higher, the economic empowerment of the community will decrease but not significantly.

CFA results analysis shows that from the KMO and Bartlett's Test table, the Kaiser Mayer Olkin (KMO) value is 0.547 where the value is greater than 0.5 . This value indicates that the data is valid for further analysis by factor analysis. Bartlett test value is 53.965 with a significant value of 0.002 below $5 \%$, then the correlation matrix formed is an identity matrix, or in other words, the factor model used is good. Furthermore, to see which variables have communalities correlation values above or below 0.5 or above $50 \%$ can be seen in the communalities table showing the results of extraction individually. There are six variables that have a contribution that exceeds 0.5 or $50 \%$, namely the quality of service, development of access to capital, development of school facilities, development of facilities and infrastructure, skills development, and use of technology while government policy variables and access to fish resources have an extraction value below 0.5 or $50 \%$. However, the next feasibility must be tested with variance Explained. The total variance results are explained in the initial Eigenvalues table; it is known that there are only three variable components that influence the economic empowerment of the community. Eigenvalues show the relative importance of each factor in calculating the variance for the eight variables analyzed. From the table above shows that there are only three factors formed. Because the three factors have 
a total value of eigenvalues above 1 , that is, 1.881 for factor $1,1.520$ for factor 2 , and 1.208 for factor 3, so the factoring process stops at three factors that will participate in the next analysis. In the screen graph the plot shows that from one to two factors (the line from the Component Number axis $=1$ to 2), the direction of the graph decreases. Then from number 2 to 3 , the line still decreases. While from number 3 to number 4 is already below the number 1 of the Y-axis (Eigenvalues). This shows that three factors are best for summarizing the eight variables.

Having known that the three factors are the most optimal number, it can be seen in the Component Matrix table showing the distribution of the eight variables in the three factors formed. For the component, the matrix table shows a correlation above 0.5 . In factor 1 is the development of access to capital and the construction of school facilities. In factor 2, the skill development variable. While in factor 3 there is no correlation above 0.5. Furthermore, doing the rotation factor against the factors that are formed. The purpose of rotation is to clarify the variables that fall into certain factors.

\subsection{Skills Development against Community Economic Empowerment}

The Pearson correlation results show the relationship of skills development with community economic empowerment of 0.559 is at the level of moderate relations, then the results of multiple linear regression show that skills development has a significant positive effect on economic empowerment of the community where efforts to increase awareness of fish management are carried out continuously. One of the main priorities is support for the development of alternative sources of income or processing of quality fishery products and catches in the Pahlawan Village. The results of the study show that fish entrepreneurs on average have their capital in running their businesses. The capital owned is used to procure raw materials and production costs that must be incurred by fish processors. The pattern of costs assessed is production costs which consist of fixed costs and variable costs. Almost all costs incurred by fish entrepreneurs are raw material costs. The cost of raw materials is the largest cost of all costs that must be incurred. The cost of supporting materials consists of salt, ice cubes, and plastic bags. It indicates that the anchovy processing business is highly dependent on the availability of raw materials.

\subsection{Facilities and Infrastructure Construction for Community Economic Empowerment}

The results of the Pearson correlation show that the relationship between the development of facilities and infrastructure with community economic empowerment is 0.380 at a low level of relations. Then the results of multiple linear regression show that the development of facilities and infrastructure has a positive and significant effect on the economic empowerment of the community. If the infrastructure in Pahlawan village gets better then the economic empowerment of the community increases significantly. So that the results of hypothesis testing also show that the hypothesis is accepted, meaning that the construction of facilities and infrastructure has a significant effect on the economic empowerment of the community. The important thing in an area that is related to the interests of the people living in the area is the facilities available in Pahlawan Village that directly support marine resources processing activities, namely Tanjung Tiram Port or BOM Port, where fish auction and management of anchovies and anchovy are managed. Infrastructure is a capital that is needed by the community in supporting activities in various fields. 
A. I. F. Lubis, A. P. U. Siahaan, Diwayana Putri Nasution, Ade Novalina, Rusiadi, Rahmad

Sembiring, Bakhtiar Efendi and Febru Winaro

\subsection{Quality of Service towards Community Economic Empowerment}

The results of the Pearson correlation show that the relationship between service quality and community economic empowerment of 0.043 is at a shallow level of relations. Then the results of multiple linear regression showed that service quality has an adverse effect but not significant on community economic empowerment. Where the quality of service carried out by BPJS in Pahlawan Village has been resolved well only because of the lack of capital in the village. Health BPJS has participated in improving the quality of community services in Pahlawan Village in order to be quality, and also the health BPJS must be obliged to socialize the procedures to the entire Pahlawan Village community to make it easier for the community to be able to use the BPJS card. BPJS Kesehatan is essential and must be given to every fishing village of Pahlawan Village because without the control and supervision of the community BPJS Health will not be able to provide better health services. The regulation also states that BPJS Kesehatan is obliged to help people fulfill their obligations and obtain their rights. If the community actively participates in overseeing the performance and quality of BPJS Health services, there will be no wild parties who dare to deceive the community. That way, the services provided by BPJS Health can improve until eventually it is expected to become.

\subsection{Strategic Improvement of Fishermen's Welfare through Economic Empowerment of Coastal Communities}

The analytical tool used is the Analytical Hierarchy Process (AHP) which is one of the tools or models for decision making with the primary input being human perception. AHP is done to describe priority issues based on categories in general and occur in each village. By using AHP, the weighting of a factor and sub-factor can be carried out according to human perception, so that it is expected to be able to describe the actual conditions. This study aims to determine the factors and sub-factors, and which strategies influence / determine conclusively to improve their welfare.

Table 8 Strategic Priorities for Improving Fishermen's Welfare

\begin{tabular}{|c|c|}
\hline Strategy & Priority \\
\hline $\begin{array}{c}\text { Skill development strategy in the community with priority skills training activities according to the } \\
\text { needs of fishermen in Pahlawan Village and fishing techniques and processing }\end{array}$ & 1 \\
\hline Development strategy of facilities and infrastructure seen from infrastructure & 2 \\
\hline BPJS service quality strategy in Pahlawan Village & 3 \\
\hline Development strategy for capital access & 4 \\
\hline Government policy strategy & 6 \\
\hline School facility development strategy & 7 \\
\hline Fisheries resource access strategy & 8 \\
\hline
\end{tabular}

Based on the table above shows the priority of fishermen improvement strategies in Pahlawan Village that can be done to improve the welfare of fishers in Pahlawan Village in the coastal area of Tanjung Tiram District. According to the perception of groups of community leaders, fishermen, and government institutions that the main priority in the strategy to improve the welfare of fishers in Pahlawan Village is a community skill development strategy. Perceptions of groups of community leaders, fishermen, and government agencies assessed that the fishermen of Pahlawan Village could be enhanced through the mastery of science and technology. That is in line with their development in the fishing business or other fields that can broaden the thinking horizons of coastal communities who have been provided with a variety of knowledge and technology will be able to adapt quickly to environmental changes that occur, both those that have positive and negative 
impacts. A job opportunity that is available as a positive impact of the development of the coastal area will be able to be responded positively if the human resources of the fishermen are equipped with excellent skills. Likewise, adequate adjustments will be made by the competent fishermen of Pahlawan Village with changes in the existing environment on the beach and the sea. Besides, according to groups of community leaders and the government, the character of reliable human resources will make the fishermen manage financial resources well, so that fish business and other businesses can be appropriately handled. It is in line with various government programs that require reliable human resources in financial management so that the assistance provided can be used sustainably.

\section{REFERENCES}

[1] M. Dharma Tuah Putra Nasution et al., "Decision Support Rating System with Analytical Hierarchy Process Method," Int. J. Eng. Technol., vol. 7, no. 2.3, pp. 105-108, Mar. 2018.

[2] Y. Rossanty, S. Aryza, M. D. T. P. Nasution, and A. P. U. Siahaan, "Design service of QFD and SPC methods in the process performance potential gain and customers value in a company,” Int. J. Civ. Eng. Technol., vol. 9, no. 6, 2018.

[3] A. Ikhwan, M. Yetri, Y. Syahra, and J. Halim, "A Novelty of Data Mining for Promoting Education based on FP-Growth Algorithm," Int. J. Civ. Eng. Technol., vol. 9, no. 7, pp. 1660-1669, 2018.

[4] L. W. Honens, "Promoting Skill Development," in IEEE-USA Seventh Biennial Careers Conference 'Change \& Competitiveness \& Careers, pp. 200-205.

[5] R. Rahim et al., "TOPSIS Method Application for Decision Support System in Internal Control for Selecting Best Employees," J. Phys. Conf. Ser., vol. 1028, p. 012052, Jun. 2018.

[6] H. A. Hasibuan, R. B. Purba, and A. P. U. Siahaan, "Productivity Assessment (Performance, Motivation, and Job Training) using Profile Matching," Int. J. Econ. Manag. Stud., vol. 3, no. 6, pp. 73-77, 2016.

[7] K. Kristianti and B. L., Strategi Bertahan Hidup Nelayan Buruh di Desa Meskom Kecamatan Bengkalis Kabupaten Bengkalis Provinsi Riau. Berkala Perikanan Terubuk, 2014.

[8] P. K. Sullivan and V. Dayananda, "Engineering Management Considerations In Coastal Development," in OCEANS 91 Proceedings, pp. 1430-1430.

[9] M. Mestres, A. Sánchez-Arcilla, J. P. Sierra, C. Mösso, J. González del Río, and M. Rodilla, "Basis and tools for a sustainable development of estuaries and coastal areas," Manag. Environ. Qual. An Int. J., vol. 15, no. 1, pp. 25-32, Feb. 2004.

[10] M. D. T. P. Nasution, Y. Rossanty, P. B. Sari, and A. P. U. Siahaan, "Online Shoppers Acceptance: an Exploratory Study,” Int. J. Civ. Eng. Technol., vol. 9, no. 6, pp. 793-799, 2018.

[11] C. Wang and H. Xie, "Status and development trend of coastal environment evolution based on RS," in 2010 Second IITA International Conference on Geoscience and Remote Sensing, 2010, pp. 326-328.

[12] Y. Liu and H. An, "Based on Ecosystem Management Study Coastal Cities Development," in 2010 International Conference on Management and Service Science, 2010, pp. 1-4.

[13] L. van Riemsdijk, P. T. M. Ingenbleek, M. Houthuijs, and H. C. M. van Trijp, "Strategies for positioning animal welfare as personally relevant," Br. Food J., vol. 119, no. 9, pp. 2062-2075, Sep. 2017. 
A. I. F. Lubis, A. P. U. Siahaan, Diwayana Putri Nasution, Ade Novalina, Rusiadi, Rahmad Sembiring, Bakhtiar Efendi and Febru Winaro

[14] T. Eddy, B. Alamsyah, S. Aryza, and A. P. U. Siahaan, "An Effect Phenomena Circle Living Field in Secanggang Langkat," Int. J. Civ. Eng. Technol., vol. 9, no. 7, pp. 15751580, 2018.

[15] D. Siregar et al., "Multi-Attribute Decision Making with VIKOR Method for Any Purpose Decision," J. Phys. Conf. Ser., vol. 1019, p. 012034, Jun. 2018.

[16] A. Agrawal, "Public sector science and 'the strategy of the commons," in PICMET '01. Portland International Conference on Management of Engineering and Technology. Proceedings Vol.1: Book of Summaries (IEEE Cat. No.01CH37199), p. 280.

[17] M. I., Disertasi: Analisis dan Pengembangan Model peningkatan Kualitas Sumberdaya Manusia dan Kesejahteraan Keluarga di Wilayah Pesisir Provinsi Jawa Barat. Bogor: Sekolah Pascasarjana Institut Pertanian Bogor, 2010.

[18] M. A. Rufei, "Welfare of vertical R\&amp;amp;D cooperation and competition," in 2013 International Conference on Engineering, Management Science and Innovation (ICEMSI), 2013, pp. 1-3.

[19] Y. Rossanty, S. Aryza, M. D. T. P. Nasution, and A. P. U. Siahaan, "Design Service of QFC And SPC Methods in the Process Performance Potential Gain and Customers Value in a Company," Int. J. Civ. Eng. Technol., vol. 9, no. 6, pp. 820-829, 2018.

[20] R. Mohideen, "The implications of clean and renewable energy development for gender equality in poor communities in South Asia," in 2012 IEEE Conference on Technology and Society in Asia (T\&SA), 2012, pp. 1-6.

[21] A. H. Lubis, S. Z. S. Idrus, and A. Sarji, "ICT Usage Amongst Lecturers and Its Impact Towards Learning Process Quality," vol. 34, no. 1, pp. 284-299, 2018.

[22] D. Arul Paramanandam and P. Packirisamy, "An empirical study on the impact of micro enterprises on women empowerment," J. Enterprising Communities People Places Glob. Econ., vol. 9, no. 4, pp. 298-314, Oct. 2015.

[23] H. Martadwiprani and D. Rahmawati, "Economic Development as Community Resilience Enhancement in Minapolis Coastal Settlement," Procedia - Soc. Behav. Sci., vol. 135, pp. 106-111, Aug. 2014. 